\title{
Correlation Study between Elevation, Population Density, and Dengue Hemorrhagic Fever in Kendari City in 2014-2018
}

\author{
Siti Nurul Ainun Istiqamah ${ }^{1}$, A. Arsunan Arsin ${ }^{1 *}$, Andi Ummu Salmah ${ }^{2}$, Anwar Mallongi $^{3}$ \\ ${ }^{1}$ Department of Epidemiology, Faculty of Public Health, Hasanuddin University, Makassar, Indonesia; ${ }^{2}$ Department of \\ Reproductive Health, Faculty of Public Health, Hasanuddin University, Makassar, Indonesia; ${ }^{3}$ Department of Environmental \\ Health, Faculty of Public Health, Hasanuddin University, Makassar, Indonesia
}

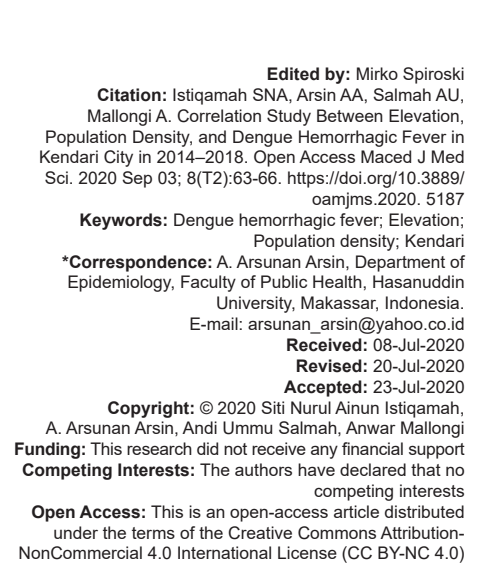

Abstract

BACKGROUND: The incidence of dengue hemorrhagic fever (DHF) has experienced rapid development throughout the world in recent decades. Indonesia was reported as the $2^{\text {nd }}$ country with the largest DHF cases among 30 endemic countries. Dengue virus can develop properly based on certain regional conditions. The elevation is an important factor that can affect the presence of dengue vector mosquitoes. High population density contributes to dengue transmission by increasing the contact between infected mosquitoes and human hosts.

AIM: This study aimed to determine the correlation between elevation and population density with the incidence of dengue in Kendari City in 2014-2018.

METHODS: This research is an observational analytic study with ecological study design. Data incidence of DHF in 2014-2018, elevation and population density were respectively obtain from the Health Office of Kendari City, Meteorology, Climatology and Geophysics Agency of Kendari City, Statistics Agency of Kendari City. The analysis of the data used in the study is univariate and bivariate analysis. Bivariate analysis using Pearson correlation test was performed.

RESULTS: The results showed that the correlation between elevation and DHF ( $p=0.014, r=0.339)$ and the correlation between population density and DHF $(p=0.186)$.

CONCLUSION: It can be concluded that there is significant correlation with positive direction between elevation and the DHF, and there is no significant correlation between population density and DHF incidence in Kendari City in 2014-2018.

\section{Introduction}

The incidence of dengue hemorrhagic fever (DHF) has experienced rapid development throughout the world in recent decades. Based on the World Health Organization, an estimated 390 million dengue infections occur each year. Cases in America, Southeast Asia, and the Western Pacific are estimated to have more than 3.2 million infected with dengue in 2015 [1]. Asia Pacific bore 75\% of the dengue burden in the world between 2004 and 2010, while Indonesia was reported as the $2^{\text {nd }}$ country with the largest DHF cases among 30 endemic countries [2].

In 2017, the number of DHF cases reported in Indonesia was 68,407 cases with an incidence rate of $26.10 / 100,000$ population and a total of 493 deaths with a case fatality rate of $0.72 \%$. Kendari City is a dengue endemic area, as many as 1093 cases were reported in 2016 with an incidence rate of $372.8 / 100,000$ population and a total of 7 deaths with a case fatality rate of $0.64 \%$ [2].

In dengue transmission, population factors are emerging along with other climatic and environmental factors [3]. Dengue virus can develop properly based on certain regional conditions. In a place with an elevation of more than $1150 \mathrm{~m}$ above sea level the chance of mosquitoes transmitting the virus is very small and in a place with an elevation of more than 1400 masl mosquitoes do not breed. The effect of height variations influences the ecological conditions required by the disease vector [4]. Several studies stated the reasons of increasing trends of dengue fever cases as population growth, urbanization, formation of slums, and increased population density [5], [6], [7]. This study aims to determine the correlation between elevation and population density with the incidence of dengue fever in Kendari City in 2014-2018.

\section{Materials and Methods}

The research was conduct in Kendari City, Southeast Sulawesi. This research is an observational analytic study with an ecological study design or population correlation study. This study aims to determine the correlation between elevation and 
population density with the incidence of dengue fever in Kendari City in 2014-2018.

The population in this study was the incidence of DHF in 2014-2018 recorded in the Health Office of Kendari City. Population correlation study aims to see the correlation between certain characteristics with the incidence of disease in the whole population so that the unit of observation in this study is the whole population.

Incidence of DHF in 2014-2018, elevation and population density were, respectively, obtain from the Health Office of Kendari City, Meteorology, Climatology and Geophysics Agency of Kendari City, Statistics Agency of Kendari City.

The analysis of the data used in the study is univariate and bivariate analysis. Bivariate analysis using Pearson correlation test was performed.

\section{Results}

Table 1 presents the results of univariate analysis of research variables based on the parameters of centering size and the size of the spread. If the distribution of data is normal, the mean and standard deviations are used as a measure of concentration and distribution. If the data distribution is not normal, then the median and percentile are used as a measure of concentration and distribution.

Table 1: Distribution of DHF occurrence, elevation, and population density in Kendari City in 2014-2018

\begin{tabular}{llllll}
\hline Variables & Min & Max & Mean & Median & Std. Deviation \\
\hline DHF events per district & 0 & 148 & 27.04 & 8.00 & 43.588 \\
Elevation (m ASL) & 3 & 45 & 21.23 & 18.39 & 10.263 \\
Population density (hectare/population) & 4.41 & 79.71 & 2034 & 16.02 & 18.51 \\
\hline DHF: Dengue hemorrhagic fever. & & & & &
\end{tabular}

Table 1 shows that the average distribution of DHF per district in Kendari City in 2014-2018 was 27 cases with the fewest cases being 0 , and the most cases were 148 cases. The average height of places in Kendari City in 2014-2018 is $21.23 \mathrm{~m}$ above sea level with a minimum height of $3 \mathrm{~m}$ above sea level and a maximum height of $45 \mathrm{~m}$ above sea level. The average population density in Kendari City in 20142018 was 20.34 ha/person with a minimum density of $4.41 \mathrm{ha} /$ person and a maximum density of $79.71 \mathrm{ha}$ person.

Table 2 presents the results of a bivariate analysis using a correlation test between the elevation and population density variables with the incidence of dengue in Kendari City in 2014-2018. Correlation test results between elevation with the incidence of dengue fever showed $p$ value $0.014<0.05$, meaning that there is a significant correlation between the elevation with the incidence of dengue in Kendari City in 2014-2018. The correlation coefficient value of 0.339 indicates the direction of a positive correlation with the strength of a weak correlation. Correlation test results between population density and dengue fever show $p$ value of $0.186>0.05$, meaning that there is no significant correlation between population density and dengue fever in Kendari City in 2014-2018.

Table 2: Correlation test between elevation and population density with DHF in 2014-2018

\begin{tabular}{lll}
\hline Variables & DHF & \\
\cline { 2 - 3 } & $\mathrm{r}$ & Sig. (two-tailed) \\
\hline Elevation & 0.339 & 0.014 \\
Population density & 0.186 & 0.186 \\
\hline DHF: Dengue hemorrhagic fever. & &
\end{tabular}

\section{Discussion}

The results showed that elevation had a correlation with the incidence of dengue in Kendari City in 2014-2018, while the population density did not have a correlation with the incidence of dengue in Kendari City in 2014-2018.

The average height of places in Kendari City in 2014-2018 is $21.23 \mathrm{~m}$ above sea level. Correlation test between elevation and DHF incidence in Kendari City in 2014-2018 showed a $p$ value of $0.014<0.05$, so it can be concluded that there is a significant correlation between elevation and DHF incidence in Kendari City in 2014-2018. The correlation coefficient value of 0.339 indicates a positive correlation with the strength of a weak correlation. A positive relationship means that the increase in height is also followed by an increase in the incidence of dengue fever.

A study conducted by Handayani et al. [8] showed that the elevation and the incidence of DHF have a moderate relationship with a negative pattern $r=-0.659$ with a significance $(p) 0.038$. This means that the lower the elevation, the higher the incidence of dengue hemorrhagic fever.

A study conducted by Kesetyaningsih et al. [9] showed that cases of dengue fever in Sleman Regency with a high category (50-80 cases/year) and very high (>80 cases/year) occurred at an elevation of $<200$ masl, especially at an elevation of 50-125 masl. Cases of dengue still occur at an elevation of 300-425 masl, even in the low category. Pearson correlation analysis showed a negative correlation between elevation and dengue cases even though the correlation strength was weak ( $p=0,000 ; r=-0.127)$. The higher an area, the lower the incidence of dengue fever.

The elevation is an important factor that can affect the presence of dengue vector mosquitoes. These factors affect the air temperature and humidity of a place that will affect the development of vector mosquitoes and dengue viruses [10]. The occurrence of dengue has also spread from low altitudes to more than 
$1000 \mathrm{~m}$ above sea level [11]. The expansion of dengue is expected to increase under the influence of increases in minimum temperature and population migrations resulting from changes in transportation, globalization, trading, social-economic condition, housing, and viral evolution [12].

A study by Sayono et al. [13] in Central Java, Indonesia, reported that Aedes mosquitoes were found to be distributed at all altitudes in the study area up to $1.200 \mathrm{~m} \mathrm{ASL}$, indicating the influence of climate change. This is the highest altitude that dengue has yet been identified, and the first time such conditions have been recorded in the area; both indicate changes in dengue vector distribution in Indonesia occurring in response to climate change.

The existence of Aedes mosquitoes at high altitudes up to $1200 \mathrm{~m} \mathrm{ASL}$ indicates that the physical and biological factors in the area are capable of supporting the mosquito lifecycle. Aedes mosquitoes have not previously been found at altitudes of $1000 \mathrm{~m}$ ASL due to the low temperature, which impedes the Aedes lifecycle [14]. People in mountainous localities use large, open cement tanks to store clean water, which have become the most common larval habitat at high altitudes [13].

The average population density in Kendari City in 2014-2018 was 20.34 ha/person with a minimum density of 4.41 ha/person and a maximum density of 79.71 ha/person. Correlation test between population density and DHF incidence in Kendari City in 20142018 showed a $p$ value of $0.186>0.05$; there was no significant correlation between population density and the incidence of dengue fever in Kendari City in 2014-2018.

A study by Sirisena et al. (2017) in Sri Lanka showed that the dengue incidence was high in areas where the population density is high, and this was clearly seen in the three major Districts, Colombo, Kandy, and Jaffna where the population density is high. The Colombo District from the Western Province has been experiencing a very high dengue incidence, and the highest number of cases reported from $2009 \pm 2014$ was from this district. The major reason behind the high number of reported cases in the Colombo District appears to be due to the high population density.

The dengue incidence is very low in the Nuwara Eliya District despite this being one of the highly populated district in the wet zone. High altitude seems to play a pivotal role in limiting the distribution of Aedes aegypti in the Nuwara Eliya district, which is situated at $1880 \mathrm{~m}$ above the sea level. Badulla District is situated in the next highest elevation of $670 \mathrm{~m}$ and has a lower population density than Nuwara Eliya, yet reported high dengue incidence in the past 5 years [15].

In India, $A$. aegypti breeding sites range from the sea level to $1000 \mathrm{~m}$ above the sea level. Lower elevations $(<500 \mathrm{~m}$ ) have moderate to heavy mosquito populations, while mountainous areas $(>500 \mathrm{~m})$ have low mosquito populations [16].

High population density is thought to contribute to dengue transmission by increasing the contact between infected mosquitoes and human hosts. However, high population density areas in São Paulo had a lower incidence of dengue compared to low population density areas [17]. These high population density areas typically consisted of large residential buildings, while the low population density areas typically consisted of individual houses. In contrast, other studies have reported that areas with a predominance of independent houses had higher levels of $A$. aegypti larval infestation [18].

A study by Handayani et al. [8] showed that the population density with the incidence of DHF has a correlation of 0.360 with $p=0.307$. Thus, it can be concluded that there is no significant positive relationship between population density with dengue fever (DHF).

Study conduct in Vietnamese reported that infrastructure characteristics (e.g., the lack of water supply), rather than population density, had the greatest effect on the transmission of dengue [5]. One previous study found that around 3000-7000 persons/ $\mathrm{km}^{2}$ in Vietnam was the condition for the highest risk for dengue epidemics, and the risk did not increase with density beyond that [5].

Studied in Mexico by Machado-Machado [19], the relative contribution of climate and socio-ecological factors was investigated by including 11 climatic variables on temperature and precipitation but only four socioecological variables in models, resulting in climatic variables having more influence on dengue transmission than socioecological factors. Relative contributions of climatic and socioecological factors were also analyzed in Singapore, where the relative risk of dengue due to population growth was 6 times higher than the relative risk associated with climate alone [20], [21], [22].

Most of these studies found a significant association between dengue and high population density. However, a single study in Argentina reported that rural areas with a low population density may experience severe epidemics in the absence of a tap water supply [17]. High population density might only facilitate the dengue transmission cycle between human beings and mosquitoes when the number of infected cases is large enough, and the trend will still need to be validated by more data in the future [5].

\section{Recommendation}

Environmental factors and climate change provide changes to the lifecycle of mosquitoes and virus evolution. Therefore, observing dengue fever trends is needed considering that this disease can become an epidemic at any time. 


\section{References}

1. World Health Organization. Dengue and Severe Dengue. Geneva: World Health Organization; 2018.

2. Kementerian Kesehatan RI. InfoDatin Situasi Demam Berdarah di Indonesia Tahun 2017. Jakarta: Kementerian Kesehatan Republik Indonesia; 2017. https://doi.org/10.14710/ jkli.19.1.27-34

3. Sang S, Gu S, Bi P, Yang W, Yang Z, Xu L. Predicting unprecedented dengue outbreak using imported cases and climatic factors in Guangzhou, 2014. PLoS Negl Trop Dis. 2015;9(5):e0003808. https://doi.org/10.1371/journal. pntd. 0003808

PMid:26020627

4. Hidayati R, Kesumawati U, Manuwoto S, Boer R, Koesmayono Y Kebutuhan satuan panas untuk fase perkembangan pada nyamuk Aedes aegypti (Diptera: Culicidae) dan periode inkubasi ekstrinsik virus dengue. J Ekolol Kesehatan. 2007;6(3):648-58.

5. Schmidt W, Suzuki $M$, Thiem VD, White RG, Tsuzuki $A$, Yoshida L, et al. Population density, water supply, and the risk of dengue fever in Vietnam: Cohort study and spatial analysis. PLoS Med. 2011;8(8):e1001082. https://doi.org/10.1371/ journal.pmed.1001082

PMid:21918642

6. Simoy MI, Simoy MV, Canziani GA. The effect of temperature on the population dynamics of Aedes aegypti. Ecol Model. 2015;314(1):100-10. https://doi.org/10.1016/j. ecolmodel.2015.07.007

7. Sumi A, Telan EF, Chagan-Yasutan H, Piolo MB, Hattori T, Kobayashi $\mathrm{N}$. Effect of temperature, relative humidity and rainfall on dengue fever and leptospirosis infections in Manila, the Philippines. Epidemiol Infect. 2017;145(1):78-86. https://doi. org/10.1017/s095026881600203x PMid:27608858

8. Handayani S, Fannya P, Roza SH, Angelia I. Analisis spasial temporal hubungan kepadatan penduduk dan ketinggian tempat dengan kejadian DBD kota padang. J Kesehatan Med Saintika. 2017;8(1):25-34.

9. Kesetyaningsih TW, Andarini S, Sudarto, Pramoedyo H. Determination of environmental factors affecting dengue incidence in Sleman district, Yogyakarta, Indonesia. Afr J Infect Dis. 2018;12(1):13-25. https://doi.org/10.21010/ajid.v12i1s.3

10. Hendri J, Santya RN, Prasetyowatil H. Distribusi dan kepadatan vektor demam berdarah dengue (DBD) berdasarkan ketinggian tempat di kabupaten Ciamis Jawa Barat. J Ekol Kesehatan. 2015;14(1):17-28. https://doi.org/10.22435/jek. v14i1.4654.17-28

11. Subedi D, Taylor-Robinson AW. Epidemiology of dengue in Nepal: History of incidence, current prevalence and strategies for future control. J Vector Borne Dis. 2016;53(1):1-7.
12. Murray NE, Quam M, Wilder-Smith A. Epidemiology of dengue: The past, present and prospects. Clin Epidemiol. 2013;5(1):299309. https://doi.org/10.2147/clep.s34440

13. Sayono S, Nurullita U, Sumanto D, Handoyo W. Altitudinal distribution of Aedes indices during dry season inthe dengue endemic area of Central Java, Indonesia. Ann Parasitol. 2017;63(3):213-21.

14. Brady OJ, Johansson MA, Guerra CA. Modelling adult Aedes aegypti and Aedes albopictus survival at different temperatures in laboratory and field settings. BMC Parasit Vectors. 2013;6(1):352. https://doi.org/10.1186/1756-3305-6-351 PMid:24330720

15. Sirisena $P$, Noordeen $F$, Kurukulasuriya $H$, Romesh $T$, Fernando L. Effect of climatic factors and population density on the distribution of dengue in Sri Lanka: A GIS Based evaluation for prediction of outbreaks. PLoS One. 2017;12(1):e0166806. https://doi.org/10.1371/journal.pone.0166806 PMid:28068339

16. Goto K, Kumarendran B, Mettananda S, Gunasekara D, Fujii Y. Analysis of effects of meteorological factors on dengue incidence in Sri Lanka using time series data. PLoS One. 2013;8(5):e63717. https://doi.org/10.1371/journal. pone. 0063717 PMid:23671694

17. Araujoa RV, Albertini MR, Costa-da-Silva AL, Suesdek L, Franceschi NC, et al. São Paulo urban heat islands have a higher incidence of dengue than other urban areas. Braz J Infect Dis. 2015;9(2):146-55. https://doi.org/10.1016/j.bjid.2014.10.004 PMid:25523076

18. Glasser CM, Arduino Mde B, Barbosa GL. Behavior ofimmatures Aedes aegypti in the coast state of Sao Paulo, Brazil. Rev Soc Bras Med Trop. 2011;44(3):49-55.

PMid:21739074

19. Machado-Machado EA. Empirical mapping of suitability to dengue fever in Mexico using species distribution modeling. Appl Geogr. 2012;33(1):82-93. https://doi.org/10.1016/j. apgeog.2011.06.011

20. Struchiner CJ, Rocklöv J, Wilder-Smith A, Massad E. Increasing dengue incidence in Singapore over the past 40 years: Population growth, climate and mobility. PLoS One. 2015;10(8):1-14. https://doi.org/10.1371/journal.pone.0136286

21. Arsunan SA. Syamsiar R, Muhammad AN, Rezki E, Aries TP, Nilawati UA, et al. Identification and strengthening of positive deviance: An efforts to reduce the incidence of malaria in Selayar Islands. Enferm Clín. 2020;30(Suppl 2):528-32. https:// doi.org/10.1016/j.enfcli.2019.07.153

22. Arsunan AA, Dwinata I, Ariyanto J, Nurdin MA, Aisyah. Positive deviance against malaria events in Majene district. Indian J Public Health Res Dev. 2019;10(10):3021. https://doi. org/10.5958/0976-5506.2019.03021.3 